\title{
Knowledge of Diabetic Patients about their Disease Status at Selected Sub-metropolitan of Nepal
}

\author{
Supendra Karkia , Srijana Pandey ${ }^{\mathrm{b}}$, Purusotam Raj Shedain ${ }^{\mathrm{c}}$, Ashok Pandey ${ }^{\mathrm{d}}$ \\ aOPJS University, Churu, Rajasthan, India. Email: supen17@gmail.com. \\ bDepartment of Community Medicine, KIST Medical College Teaching Hospital, nepal \\ ${ }^{\circ}$ Chief Hospital Development and Curative Services Division, Ministry of Social Development \\ Bagmati province Hetauda Nepal. \\ dNepal Health Research Council, Ramshah Path, Kathmandu, Nepal.
}

\begin{abstract}
Aims: Diabetes is a metabolic disorder, the effective management of which requires not only medication use but also patient diabetes knowledge for adopting necessary daily lifestyle changes. Those with better knowledge of diabetes management are expected to maintain well glycemic control. The aim of the study is to identify the extent of diabetes-related knowledge among people living with Type 2 diabetes mellitus.
\end{abstract}

Study design: Descriptive cross-sectional comparative study.

Place and Duration of Study: The study was carried out under the supervision of OPJS University and a field study was carried out in selected sub-metropolitan cities of Nepal from September 2019 to June 2020.

Methodology: A simple random sampling technique was used comprising a structured questionnaire to examine the knowledge and practices of diabetes among 415 participants. This study reports the psychometric properties of the 24-items version of the Diabetes Knowledge Questionnaire which was already validated and used by the various researchers. However, to provide content validity, the draft form of the items will be again examined by one specialist in the subject. Descriptive statistics along with inferential statistics were calculated and a $p<0.05$ was considered significant for data analysis.

Results: More than half $222(53.5 \%)$ of the male participants have poor glycemic control and $14 \%$ of them were obese. The results of the present study revealed that there was a significant relationship between the Diabetes Knowledge Questionnaire and basic information, glycemic control and prevention of complications.

Conclusions: Based on the findings, the study concluded that there are many barriers to achieving glycemic control, the most significant barrier was found to be inadequate knowledge and understanding about diabetes mellitus among people with type 2 diabetes mellitus.

Keywords: Diabetic Patients; Disease Status; Knowledge; Sub-metropolitan 


\section{Main text}

\section{INTRODUCTION}

Type 2 diabetes is a metabolic disorder. In order to manage it effectively, along with the use of medication, it also requires active patient awareness with appropriate life-style modifications. $(1,2)$. The major problem with diabetes is that if it is poorly controlled it leads to increase in complications associated with diabetes.(3) Diabetes increases the risk of various microvascular and macrovascular diseases such as stroke, coronary artery disease, kidney failure, blindness, and foot amputation(4,5) leading to an increased morbidity and mortality. However, diabetes and its complications can be controlled and prevented by properly balanced diet and effective life style management.(6,7) There is evidence that good glycemic control may prevent diabetes-related complications.(8)

Diabetes treated for lifetime thus charge associated with diabetes and its associated complications imposes an extensive financial burden on the cost of care (9) for an individual (10), society $(7,11,12)$ and the healthcare system.(13) Poor diabetes knowledge has a negative impact on selfcare behavior.(14-16)Though health education of diabetic patients has an effective role in the proper management of diabetes, there is a shortage of well trained personnel in Nepal to provide appropriate education about diabetes mellitus and its associated co-morbidities and complications.(1,17) A formal assessment of knowledge about diabetes mellitus and its management of a diabetic patients is a prerequisite. Thus, aim of our study was to assess diabetes knowledge using diabetes knowledge questionnaire (DKQ)(18) among Type 2 diabetes patients.

\section{MATERIAL AND METHODS}

A cross-sectional study was conducted in a diabetic people of sub metro politician city of Nepal from September 2019 to June 2020. The study subjects were patients previously diagnosed with Type 2 diabetes mellitus (T2DM). The sample size calculation for this study is based on the previous study where the prevalence of type 2 diabetes mellitus was $43 \%$. The formula used for calculation was, $n=z 2 \times[p(1-p)] / d 2$ with confidence interval of $95 \%$ and $5 \%$ precision level. With $z=1.96$ and $d=.05$ the total number of required participants was 377 . Considering a $10 \%$ non-response rate estimated final sample size was 415 participants. This study was approved by the ethics and research committee of the OPJS University, Rachi, India. We did the site mapping of sub metro politician city which includes ward's numbers and total population. Then, we did a site mapping of healthcare facility including a number of health facilities in each sub metro politician city (hospital, primary health center, health post, urban health center, primary health care outreach center), a health worker in each centers populations taking services in that health center, Equipment assessment in that health center, authorized person to diagnosed, number of T2DM cases with male and female 
including their age, medicine availability of T2DM cases and follow up.

The inclusion criteria were as follows: individuals 30 years of age or more, diagnosed with type 2 T2DM, who were currently using insulin, oral hypoglycemic agents or diet, understood the questions on the DKQ-24 questionnaire and signed the written informed consent. The DKQ-24 is a valid and reliable instrument that evaluates the knowledge related to T2DM. It has an alpha Cronbach of 0.78 , is relatively easy to administer, and is validated in the Nepali population. The aspects to evaluate include basic information (10 items) glycemic control (7 items) and the prevention of complications (7 items). It has three response options (yes, no, I don't know).

As proposed by the author of validation for Nepali, the questionnaire was coded in the right answers (1), wrong (0) and do not know (2). Subsequently, and for the presentation and analysis of the results of the sample, modified in a dichotomous scale ( 1 and 0$)$ to distinguish between the presence of knowledge and presence of unknowns and misconceptions, being transformed into one of the answers that match the right answer for the desired variable (e.g. knowledge: right answer = 1) and the rest to 0 (for wrong answers or ignorance).

American Diabetes Association (ADA) guideline was used to define glycemic control in this study. Patients with values of $\mathrm{HbA} 1 \mathrm{c}<7 \%$ were classified as "good glycemic control", whereas those with $\mathrm{HbA} 1 \mathrm{c} \geq 7 \%$ were classified as "poor glycemic control". Cronbach's alpha for the knowledge score was 0.933 in 24 scales of DKQ-24. Statistical tests were considered significant at $p<0.05$. A cutoff point of 7 was considered "sufficient knowledge" by researcher consensus. Data were entered using the Epi data 3.02 version (www.epidata.dk). Data analysis was done by studying and coding the responses from the questionnaires. The range and consistency check was made to ensure accuracy, and Statistical Analysis Data were analyzed by Statistical Package for Social Science (SPSS 24.0. Inc., Chicago, IL, USA). Demographic and clinical variables were presented by using descriptive statistics. Data distribution was analyzed by the principal component analysis (PCA) to compare groups with non-normal distribution. Patients with values of $\mathrm{HbA} 1 \mathrm{c}<0.05$. The ethical approval was taken from ethical committee of OPJS university, India.

\section{RESULTS}

Knowledge Assessment 
More than half $222(53.5 \%)$ of the male participants were poor glycemic control followed by $139(33.5 \%)$ of female participants. The $58(14 \%)$ of the male participants BMI were obese followed by $37(8.9 \%)$. (Table 1$)$

Table 1. Sociodemographic distribution of participants $(\mathrm{N}=415)$

\begin{tabular}{|c|c|c|c|c|}
\hline \multirow{2}{*}{$\begin{array}{l}\text { Variables } \\
\text { Religion }\end{array}$} & \multicolumn{2}{|c|}{ Male } & \multicolumn{2}{|c|}{ Female } \\
\hline & ${ }^{*} \mathrm{~F}$ & ${ }^{*} \mathbf{P}$ & ${ }^{\star} \mathrm{F}$ & ${ }^{*} \mathbf{P}$ \\
\hline Hindu & 190 & 45.8 & 142 & 34.2 \\
\hline Buddhist & 26 & 6.3 & 20 & 4.8 \\
\hline Christian & 9 & 2.2 & 2 & 0.5 \\
\hline Muslim & 6 & 1.4 & 4 & 1.0 \\
\hline No religion & 7 & 1.7 & 9 & 2.2 \\
\hline \multicolumn{5}{|l|}{ Ethnic background } \\
\hline Dalit & 16 & 3.9 & 16 & 3.9 \\
\hline Disadvantage Janatatis & 27 & 6.5 & 21 & 5.1 \\
\hline $\begin{array}{l}\text { Disadvantaged non-dalit Terai group (except } \\
\text { Terai Brahmin) }\end{array}$ & 21 & 5.1 & 11 & 2.7 \\
\hline Religious minorities & 10 & 2.4 & 6 & 1.4 \\
\hline Advantaged Janajatis & 86 & 20.7 & 65 & 15.7 \\
\hline Upper Caste & 78 & 18.8 & 58 & 14.0 \\
\hline \multicolumn{5}{|l|}{ Highest level of education } \\
\hline Informal education & 47 & 11.3 & 34 & 8.2 \\
\hline No schooling & 24 & 5.8 & 12 & 2.9 \\
\hline Primary (grade 1-5) & 41 & 9.9 & 16 & 3.9 \\
\hline Lower secondary (grade 6-8) & 73 & 17.6 & 64 & 15.4 \\
\hline Secondary (grade 9-10) & 14 & 3.4 & 13 & 3.1 \\
\hline Higher secondary (grade 11-12) & 25 & 6.0 & 29 & 7.0 \\
\hline Graduate and above (Bachelors and above) & 14 & 3.4 & 9 & 2.2 \\
\hline \multicolumn{5}{|l|}{ Marital status } \\
\hline Unmarried/ Never married & 31 & 7.5 & 18 & 4.3 \\
\hline Married & 155 & 37.3 & 111 & 26.7 \\
\hline Widowed & 19 & 4.6 & 15 & 3.6 \\
\hline Divorced & 7 & 1.7 & 10 & 2.4 \\
\hline Separated & 16 & 3.9 & 17 & 4.1 \\
\hline De-facto/ cohabitating & 10 & 2.4 & 6 & 1.4 \\
\hline \multicolumn{5}{|l|}{ Occupation } \\
\hline Salaried job & 31 & 7.5 & 12 & 2.9 \\
\hline Business & 75 & 18.1 & 48 & 11.6 \\
\hline Wage-based labour & 19 & 4.6 & 20 & 4.8 \\
\hline Small-informal business & 33 & 8.0 & 35 & 8.4 \\
\hline Agricultural work & 35 & 8.4 & 23 & 5.5 \\
\hline Housewife/househusband & 8 & 1.9 & 13 & 3.1 \\
\hline
\end{tabular}




\begin{tabular}{|l|r|r|r|r|}
\hline Variables & \multicolumn{3}{|c|}{ Male } & \multicolumn{3}{|c|}{ Female } \\
\hline Student & 5 & 1.2 & 5 & 1.2 \\
\hline Retired & 26 & 6.3 & 19 & 4.6 \\
\hline Others & 6 & 1.4 & 2 & 0.5 \\
\hline BMI & 5 & 1.2 & 4 & 1.0 \\
\hline Underweight $(<18.5)$ & 76 & 18.3 & 65 & 15.7 \\
\hline Normal (18.5-<25) & 99 & 23.9 & 71 & 17.1 \\
\hline Overweight (25-<30) & 58 & 14.0 & 37 & 8.9 \\
\hline Obese & 16 & 3.9 & 38 & 9.2 \\
\hline HBA1C & & & & \\
\hline $\begin{array}{l}\text { HbA1c<7\% were classified as "good glycemic } \\
\text { control" }\end{array}$ & & 53.5 & 139 & 33.5 \\
\hline $\begin{array}{l}\text { HbA1c>7\% were classified as "poor glycemic } \\
\text { control" }\end{array}$ & 222 & & & \\
\hline
\end{tabular}

${ }^{*}$ F=Frequency; ${ }^{*} \mathrm{P}=$ Percentage

The mean knowledge score was 12.97. Cronbach's alpha for the knowledge score was 0.930 in 24 scales of DKQ-24. (Table 2).

Table 2. Reliability test

\begin{tabular}{|l|r|}
\hline Scales & \multicolumn{2}{|l|}{$\begin{array}{l}\text { Cronbach's } \\
\text { alpha }\end{array}$} \\
\hline Eating too much sugar and other sweet foods is a cause of diabetes. & 0.932 \\
\hline The usual cause of diabetes is lack of effective insulin in the body. & 0.932 \\
\hline Diabetes is caused by failure of the kidneys to keep sugar out of the urine. & 0.931 \\
\hline Kidneys produce insulin. & 0.934 \\
\hline In untreated diabetes, the amount of sugar in the blood usually increases. & 0.931 \\
\hline If I am diabetic, my children have a higher chance of being diabetic. & 0.929 \\
\hline Diabetes can be cured. & 0.939 \\
\hline A fasting blood sugar level of 210 is too high. & 0.932 \\
\hline The best way to check my diabetes is by testing my urine. & 0.929 \\
\hline $\begin{array}{l}\text { Regular exercise will increase the need for insulin or other diabetic } \\
\text { medication. }\end{array}$ & 0.929 \\
\hline $\begin{array}{l}\text { There are two main types of diabetes: Type 1 (insulin-dependent) and Type } \\
\text { 2 (non-insulin-dependent). }\end{array}$ & 0.929 \\
\hline An insulin reaction is caused by too much food. & 0.928 \\
\hline
\end{tabular}




\begin{tabular}{|l|r|}
\hline Scales & \multicolumn{2}{|l|}{ Cronbach's } \\
alpha \\
\hline Medication is more important than diet and exercise to control my diabetes. & 0.928 \\
\hline Diabetes often causes poor circulation. & 0.927 \\
\hline Cuts and abrasions on diabetics heal more slowly & 0.927 \\
\hline Diabetics should take extra care when cutting their toenails. & 0.927 \\
\hline A person with diabetes should cleanse a cut with iodine and alcohol. & 0.927 \\
\hline The way I prepare my food is as important as the foods I eat. & 0.927 \\
\hline Diabetes can damage my kidneys. & 0.928 \\
\hline Diabetes can cause loss of feeling in my hands, fingers, and feet. & 0.929 \\
\hline Shaking and sweating are signs of high blood sugar. & 0.931 \\
\hline Frequent urination and thirst are signs of low blood sugar. & 0.930 \\
\hline Tight elastic hose or socks are not bad for diabetics. & 0.929 \\
\hline A diabetic diet consists mostly of special foods. & 0.930 \\
\hline
\end{tabular}

After testing the reliability, 13 scale Cronbach's Alpha value 0.930 were found. In fact, $33 \%$ had 'good knowledge', 33\% had 'fair knowledge', and 67\% had 'poor knowledge'. Percentages of correct answers to questions on DKQ-24 are shown in Table 3.

\section{Table 3. Diabetes Knowledge questionnaire (DKQ)}

\begin{tabular}{|c|c|c|c|c|c|c|}
\hline \multirow{2}{*}{$\begin{array}{l}\text { DKQ } \\
\text { Basic information }\end{array}$} & \multicolumn{2}{|c|}{$\begin{array}{l}\text { Correct } \\
\text { answer }\end{array}$} & \multicolumn{2}{|c|}{$\begin{array}{l}\text { Wrong } \\
\text { answer }\end{array}$} & \multicolumn{2}{|c|}{ Don't know } \\
\hline & $\mathrm{F}$ & $P$ & $\mathrm{~F}$ & $P$ & $F$ & $P$ \\
\hline $\begin{array}{l}\text { Eating too much sugar and other sweet foods is a } \\
\text { cause of diabetes. }\end{array}$ & 225 & 54.2 & 167 & 40.2 & 23 & 5.5 \\
\hline $\begin{array}{l}\text { The usual cause of diabetes is lack of effective insulin } \\
\text { in the body. }\end{array}$ & 230 & 55.4 & 141 & 34.0 & 44 & 10.6 \\
\hline $\begin{array}{l}\text { Diabetes is caused by failure of the kidneys to keep } \\
\text { sugar out of the urine. }\end{array}$ & 222 & 53.5 & 145 & 34.9 & 48 & 11.6 \\
\hline Kidneys produce insulin. & 151 & 36.4 & 203 & 48.9 & 61 & 14.7 \\
\hline $\begin{array}{l}\text { In untreated diabetes, the amount of sugar in the blood } \\
\text { usually increases. }\end{array}$ & 200 & 48.2 & 181 & 43.6 & 34 & 8.2 \\
\hline $\begin{array}{l}\text { If I am diabetic, my children have a higher chance of } \\
\text { being diabetic. }\end{array}$ & 128 & 30.8 & 256 & 61.7 & 31 & 7.5 \\
\hline Diabetes can be cured. & 213 & 51.3 & 99 & 23.9 & 103 & 24.8 \\
\hline A fasting blood sugar level of 210 is too high. & 178 & 42.9 & 216 & 52.0 & 21 & 5.1 \\
\hline $\begin{array}{l}\text { The best way to check my diabetes is by testing my } \\
\text { urine. }\end{array}$ & 268 & 64.6 & 112 & 27.0 & 35 & 8.4 \\
\hline $\begin{array}{l}\text { Regular exercise will increase the need for insulin or } \\
\text { other diabetic medication. }\end{array}$ & 199 & 48.0 & 146 & 35.2 & 70 & 16.9 \\
\hline
\end{tabular}




\begin{tabular}{|l|r|r|r|r|r|r|r|}
\hline DKQ & \multicolumn{2}{|c|}{$\begin{array}{l}\text { Correct } \\
\text { answer }\end{array}$} & \multicolumn{2}{|l|}{$\begin{array}{l}\text { Wrong } \\
\text { answer }\end{array}$} & \multicolumn{2}{l|}{ Don't know } \\
\hline $\begin{array}{l}\text { There are two main types of diabetes: Type 1 (insulin- } \\
\text { dependent) and Type 2 (non-insulin-dependent). }\end{array}$ & 210 & 50.6 & 164 & 39.5 & 41 & 9.9 \\
\hline Glycemic control & 176 & 42.4 & 179 & 43.1 & 60 & 14.5 \\
\hline An insulin reaction is caused by too much food. & 324 & 78.1 & 41 & 9.9 & 50 & 12.0 \\
\hline $\begin{array}{l}\text { Medication is more important than diet and exercise to } \\
\text { control my diabetes. }\end{array}$ & 30 & 7.2 & 314 & 75.7 & 71 & 17.1 \\
\hline Diabetes often causes poor circulation. & 79 & 19.0 & 257 & 61.9 & 79 & 19.0 \\
\hline Cuts and abrasions on diabetics heal more slowly & 117 & 28.2 & 200 & 48.2 & 98 & 23.6 \\
\hline $\begin{array}{l}\text { Diabetics should take extra care when cutting their } \\
\text { toenails. }\end{array}$ & 204 & 49.2 & 117 & 28.2 & 94 & 22.7 \\
\hline $\begin{array}{l}\text { A person with diabetes should cleanse a cut with } \\
\text { iodine and alcohol. }\end{array}$ & 117 & 28.2 & 214 & 51.6 & 84 & 20.2 \\
\hline Prevention of complications & 130 & 31.3 & 197 & 47.5 & 88 & 21.2 \\
\hline $\begin{array}{l}\text { The way I prepare my food is as important as the foods } \\
\text { I eat. }\end{array}$ & 80 & 19.3 & 262 & 63.1 & 73 & 17.6 \\
\hline Diabetes can damage my kidneys. & 289 & 69.6 & 62 & 14.9 & 64 & 15.4 \\
\hline $\begin{array}{l}\text { Diabetes can cause loss of feeling in my hands, } \\
\text { fingers, and feet. }\end{array}$ & 288 & 69.4 & 73 & 17.6 & 54 & 13.0 \\
\hline Shaking and sweating are signs of high blood sugar. & 294 & 70.8 & 78 & 18.8 & 43 & 10.4 \\
\hline $\begin{array}{l}\text { Frequent urination and thirst are signs of low blood } \\
\text { sugar. }\end{array}$ & 294 & 70.8 & 90 & 21.7 & 31 & 7.5 \\
\hline Tight elastic hose or socks are not bad for diabetics. &
\end{tabular}

The Kaiser-Meyer-Olkin Measure of sampling adequacy test shows the significant association $p$ value $(<0.001)$ and the Kaiser-Meyer-Olkin value 0.896 . The three PCA component are basic information, glycemic control and prevention of complications (Table 4)

Table 4. Principal Component Analysis (PCA) on the component of DKQ

\begin{tabular}{|l|l|r|}
\hline SN & PCA on the component of DKQ & $\begin{array}{l}\text { Component } \\
\text { values }\end{array}$ \\
\hline \multicolumn{2}{|l|}{ Basic information } \\
\hline 1 & Eating too much sugar and other sweet foods is a cause of diabetes. & 0.643 \\
\hline 2 & \begin{tabular}{l} 
The usual cause of diabetes is lack of effective insulin in the body. \\
\hline 3
\end{tabular} & $\begin{array}{l}\text { Diabetes is caused by failure of the kidneys to keep sugar out of the } \\
\text { urine. }\end{array}$ \\
\hline
\end{tabular}




\begin{tabular}{|c|c|c|}
\hline SN & PCA on the component of DKQ & $\begin{array}{l}\text { Component } \\
\text { values }\end{array}$ \\
\hline 4 & Kidneys produce insulin. & 0.682 \\
\hline 5 & $\begin{array}{l}\text { In untreated diabetes, the amount of sugar in the blood usually } \\
\text { increases. }\end{array}$ & 0.859 \\
\hline 6 & If I am diabetic, my children have a higher chance of being diabetic. & 0.883 \\
\hline 7 & Diabetes can be cured. & 0.864 \\
\hline 8 & A fasting blood sugar level of 210 is too high. & 0.847 \\
\hline 9 & The best way to check my diabetes is by testing my urine. & 0.801 \\
\hline 10 & $\begin{array}{l}\text { Regular exercise will increase the need for insulin or other diabetic } \\
\text { medication. }\end{array}$ & 0.818 \\
\hline \multicolumn{3}{|c|}{ Glycemic control } \\
\hline 1 & $\begin{array}{l}\text { There are two main types of diabetes: Type } 1 \text { (insulin-dependent) and } \\
\text { Type } 2 \text { (non-insulin-dependent). }\end{array}$ & 0.846 \\
\hline 2 & An insulin reaction is caused by too much food. & 0.749 \\
\hline 3 & $\begin{array}{l}\text { Medication is more important than diet and exercise to control my } \\
\text { diabetes. }\end{array}$ & 0.825 \\
\hline 4 & Diabetes often causes poor circulation. & 0.872 \\
\hline 5 & Cuts and abrasions on diabetics heal more slowly & 0.917 \\
\hline 6 & Diabetics should take extra care when cutting their toenails0. & 0.973 \\
\hline 7 & A person with diabetes should cleanse a cut with iodine and alcohol. & 0.973 \\
\hline \multicolumn{3}{|c|}{ Prevention of complications } \\
\hline 1 & The way I prepare my food is as important as the foods I eat. & 0.973 \\
\hline 2 & Diabetes can damage my kidneys. & 0.947 \\
\hline 3 & Diabetes can cause loss of feeling in my hands, fingers, and feet. & 0.839 \\
\hline 4 & Shaking and sweating are signs of high blood sugar. & 0.909 \\
\hline 5 & Frequent urination and thirst are signs of low blood sugar. & 0.951 \\
\hline 6 & Tight elastic hose or socks are not bad for diabetics. & 0.979 \\
\hline 7 & A diabetic diet consists mostly of special foods. & 0.885 \\
\hline
\end{tabular}

The principal component analysis (PCA) value shows the significant association $p<0.001$. (Table 5 )

Table 5. Scoring between the PCA component

\begin{tabular}{|l|l|l|l|l|l|l|}
\hline PCA (415) & Mean & std. & t & Mean & Lower & Upper \\
\hline
\end{tabular}




\begin{tabular}{|l|r|r|r|r|r|r|}
\hline & & deviation & & difference & & \\
\hline $\begin{array}{l}\text { Basic information (10 } \\
\text { items) }\end{array}$ & 5.6723 & 1.47231 & 78.484 & 5.67229 & 5.5302 & 5.8144 \\
\hline $\begin{array}{l}\text { Glycemic control (7 } \\
\text { items) }\end{array}$ & 3.2386 & 0.52792 & 124.970 & 3.23855 & 3.1876 & 3.2895 \\
\hline $\begin{array}{l}\text { Prevention of } \\
\text { complications (7 items) }\end{array}$ & 4.0578 & 1.15325 & 71.680 & 4.05783 & 3.9466 & 4.1691 \\
\hline
\end{tabular}

${ }^{*} 95 \%$ Confidence Interval of the Difference, $p<0.001$

\section{DISCUSSION AND CONCLUSION}

Researchers have focused more attention on the issues of the knowledge on the management of diabetes among diabetic patients. Most studies on the knowledge, attitude, and practices of diabetes done in Nepal and elsewhere target patients with diabetes. $(2,14,16,19)$ Unlike these, this study targeted the diabetic patients. A formal assessment of diabetes knowledge of subjects with diabetes can be carried out by administering the DKQ in daily clinical practice with this simple DKQ either with written or oral evaluation. Process of identification of areas where patient's diabetes knowledge could be improved with diabetes education is easy with this DKQ. The input was obtained from people with diabetes and draft a questionnaire was pilot-tested on a small group of people with diabetes, and their feedback was collected and included in modified DKQ prior to conducting this pilot study.

The majority of the low level of knowledge among diabetes patients was recorded in males. $(19,20)$ Besides this, the majority of the patients had a family history of glycemic control, which thus served as one of the major causes of diabetes among patients(21-24). Supported the idea where the majority of the male patients have poor knowledge about glycemic controls.

In this present study, we have noticed that there is an association between $\mathrm{HbA1c}$ levels and patient diabetes knowledge. There are many barriers to achieving glycemic control, the most significant barrier was found to be inadequate knowledge and understanding about diabetes among people with diabetes. $(25,26)$ The poor diabetes knowledge, which might be acting as a barrier to achieving glycemic target goals. In this present study diabetic disease duration significantly correlated with DKQ score and it is similar to findings of other investigators. $(19,20,24,27)$ The results of the present study revealed that there was a significant relationship between DKQ and basic information, glycemic control and prevention of complications.

\section{ACKNOWLEDGEMENT}

The support of the OPJS University and the research participants are appreciated.

\section{REFERENCE}

1. Abouammoh NA, Alshamrani MA. Knowledge about Diabetes and Glycemic Control among Diabetic Patients in Saudi Arabia. Journal of Diabetes Research. 2020;2020.

2. Shrestha N Y. Diabetes Knowledge and Associated Factors among Diabetes Patients in 
Central Nepal. International Journal of Collaborative Research on Internal Medicine \& Public Health. 2015;7(5):82-91.

3. Piryani S, Baral KP, Pradhan B, Poudyal AK, Piryani RM. Overweight and its associated risk factors among urban school adolescents in Nepal: A cross-sectional study. BMJ Open.

2016;6(5):1-6.

4. Kupris GM. Perceived and Actual Level of Knowledge of Diabetes Mellitus Among Nurses. 1991;

5. Id BG, Rune M, Hansen H, Povlsen MB, Neupane D, Andersen PK, et al. control of type 2 diabetes in a semi-urban area of Nepal : Findings from a cross-sectional study conducted as a part of COBIN-D trial. 2018;(Ci):1-16.

6. Carrillo Alarcon LC. Level of Knowledge in Patients with Type 2 Diabetes Mellitus and its Relationship with Glycemic Levels and Stages of Grief According to Kübler-Ross. Journal of Diabetes \& Metabolism. 2015;06(02).

7. Pandit R, Yadav R, Pandey A. Organizational Role Stress among Health Science Faculty Members of Kathmandu, Nepal. Asian Journal of Medicine and Health. 2017;6(2):1-6.

8. Gautam A, Bhatta DN, Aryal UR. Diabetes related health knowledge, attitude and practice among diabetic patients in Nepal. 2015;1-8.

9. Selvan VT. Study on role of technology in Human Resources management. 2015;1(7):4725.

10. Weeks DL, French BF, Davis AD, Towle LA. Development and validation of the Diabetes Knowledge Assessment Test for use in medical rehabilitation. 2015;37(9):802-11.

11. Garcia AA, Villagomez ET, Brown SA, Kouzekanani K, Hanis CL. The Starr County Diabetes Education Study: Development of the Spanish-language diabetes knowledge questionnaire. Diabetes Care. 2001;24(1):16-21.

12. Bukhsh A, Khan TM, Nawaz MS, Ahmed HS, Chan KG, Goh BH. Association of diabetes knowledge with glycemic control and self-care practices among pakistani people with type 2 diabetes mellitus. Diabetes, Metabolic Syndrome and Obesity: Targets and Therapy. 2019;12(August):1409-17.

13. Olusanya BO, Wright SM, Nair MKC, Boo N-Y, Halpern R, Kuper H, et al. Global Burden of Childhood Epilepsy, Intellectual Disability, and Sensory Impairments. Pediatrics. 2020 Jun 17;146(1):e20192623.

14. Tharu RP, Rawal S. Knowledge and attitude regarding risk factors of cardio vascular disease among general people residing in Nepalgunj, Banke; Nepal. 2020;(Cvd):1-20.

15. Poudel K, Sumi N. Knowledge about Risk Factors for Cancer among Adults in Nepal. KnE Life Sciences. 2018;4(4):126.

16. Sapkota Y. Knowledge, Attitude and Practice of Type 2 Diabetic Patients Visiting Diabetic OPD of TUTH and Non Diabetic Population of Kathmand. Journal of Diabetes and Endocrinology Association of Nepal. 2018;2(1):17-23.

17. Huis In T Veld EMJ, Makine C, Nouwen A, Karşda Ç, Kadioğlu P, Karşda K, et al. Validation of the Turkish version of the problem areas in diabetes scale. Cardiovascular Psychiatry and Neurology. 2011;2011.

18. Garcia AA, Villagomez ET, Brown SA, Kouzekanani K, Hanis CL. The Starr County Diabetes Education Study. Diabetes Care. 2001;24(1):16-21.

19. Gyawali B, Ferrario A, van Teijlingen E, Kallestrup P. Challenges in diabetes mellitus type 2 management in Nepal: a literature review. Global Health Action. 2016;9(1):1-12.

20. Gautam A, Bhatta DN, Aryal RU. Diabetes related health knowledge, attitude and practice among diabetic patients in Nepal. BMC Endocrine Disorders. 2015;15(1).

21. Salman Saad K. Knowledge of Diabetic Patients towards Diabetes Mellitus in a Sample of 
Patients Attending Diabetes and Endocrine Center. Journal of Pediatrics, Perinatology and Child Health. 2019;03(01):18-26.

22. Otero LM, Zanetti ML, Ogrizio MD, Otero M, Zanetti L. knowledge of diabetic patients about their disease before and after implementing a diabetes education program 1.

2008;16(2):231-7.

23. Singh R, Maharjan P. International Journal of Health Sciences and Research Knowledge of Diabetes among Diabetic Patients Attending Diabetes Clinic in. 2019;(October).

24. Rn IIA, Al Sarihin KK, Bani-Khaled MH, Althwabia II, Haddad FH. Diabetes Knowledge among Patients with Diabetes Mellitus at King Hussein Hospital. Jrms. 2012;19(1):72-7.

25. Collins GS, Mughal S, Barnett AH, Fitzgerald J, Lloyd CE. Modification and validation of the Revised Diabetes Knowledge Scale. Diabetic Medicine. 2011;28(3):306-10.

26. Dawson AZ, Walker RJ, Egede LE. Differential Relationships Between Diabetes Knowledge Scales and Diabetes Outcomes. Diabetes Educator. 2017;43(4):360-6.

27. Thushara C, Sreeja PA, Radhakrishnan AP. International Journal of Research in Assessment of level of knowledge and to explore association between knowledge and diabetic complications among type 2 diabetes mellitus patients. 2017;6(2):218-23. 